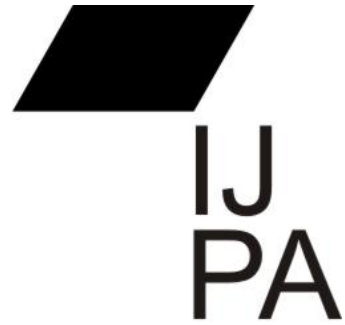

ISSN $2460-0369$

\title{
REALIZING FOOD SECURITY AND POVERTY ALLEVIATION THROUGH RURAL COMMUNITY EMPOWERMENT IN RINGINKEMBAR VILLAGE MALANG REGENCY
}

Theresia Octastefani

Department of Political Science in Security Resource Management, Burapha University, Thailand theresiaoctastefani@gmail.com

\begin{abstract}
Two-thirds of Ringinkembar Village's total population is poor people, so to meet their daily food needs are extremely difficult and limited. To solve it, one of government's strategies is implementing Food Independent Village Program. This program focuses on the effort to empower community in order to achieve food security and alleviate poverty. The research method used was descriptive method with qualitative approach. The selection of key informants is done by purposive sampling and data was analyzed using interactive data analysis model by Miles and Huberman. The results showed that: before implementing these programs, the food security condition was proved very weak and vulnerable; after implementing these programs, the condition of food security in this village more strengthen and can develop other productive business. It can realize through the entire process of rural community empowerment that was done through four stages and successfully run by the poor household.
\end{abstract}

Keywords: Food Security, Poverty Alleviation, Rural Community Empowerment 


\section{INTRODUCTION}

Indonesia is the fourth highest population country in the world after China, India, and the United States. As a country with a huge population and has a very wide area, the Indonesian Government has obligation to fulfill the needs of every citizen. One of the human needs that must be met is food because it is not only a basic need but also a basic right. Due to food is a basic right, so both central and local government must be able to ensure and protect every human right to adequate food, to be free from hunger, food insecurity, and malnutrition. The 1994 UNDP Report (cited in Tadjbakhsh, 2008, p.3) also classify food in one of the elements of human security because food security is very important aspect for human being. Moreover, in Law No. 7 of 1996 on Food, food security is defined as "a condition when all people in the household have sufficient food at all times, represented as sufficient quality of food in safe and achievable conditions". Based on these definitions, the fulfillment of food for each household in every area both urban and rural is the target of food security because Indonesia as a home to total population of nearly 250 million peoples.

Since local autonomy implemented, every area should be able to achieve local food security, so it can fulfill the needs of food for every household. It is also line with the Government Regulation No. 38 of 2007 on Division of Government Affairs between the Central Government, Provincial Government, and Regency/City Government in article 2 paragraphs 4 which stated that food security became one of the obligatory services of local government. So, in order to achieve food security, every local government has authority to manage their areas. But, in the process to achieve food security among areas to one another cannot be evenly balanced, because it has differences in the conditions, potential resources, and the number of people who lives under poverty line. Ironically instead of food security are realized, but raises a condition of food insecurity. Life Sciences Research Office (1990) was defined that food insecurity is limited or uncertain availability of nutritionally adequate and safe foods or limited or uncertain ability to acquire acceptable foods in socially acceptable ways. Moreover, this was also confirmed by Food Security Council of Indonesia, Ministry of Agriculture, and WFP (2009, p.18) in FSVA Report 2009 stated that there are 100 regencies from 346 regencies in 32 provinces enter in food insecurity conditions and requires immediate attention.

One of these regencies is Malang Regency. Malang Regency is the second largest regency area in East Java Province, has 33 sub-districts, and also known as a rich area in natural potential resources. Moreover, based on data from Central Board of Malang Regency Statistics (2010), the agricultural sector becomes one of the leading sectors of Malang Regency, because it gives contribution approximately $30 \%$ to Gross Regional Domestic Product (GRDP). But unfortunately, although the agricultural sector is one of the leading sectors, but in the reality, there are still some villages are 
scattered in various sub-districts and categorized in the rural food insecurity because it has gap in agricultural production and the high number of poverty. To overcome these problems, one of efforts made by the government is implementing Food Independent Village Program (or in Indonesian formerly known as Program Desa Mandiri Pangan). Basically, Food Independent Village Program is one of the community empowerment program created by the Central Government with Food Security Council and the Ministry of Agriculture to address food insecurity and alleviate rural poverty, and then continued to Local Government to be implemented jointly with the Department of Agriculture and The Agency of Food Security and Implementing Counseling. This program was started to implement in Ringinkembar Village, Sumbermanjing Wetan Subdistrict, Malang Regency since 2009 until 2013. In this case, this village selected to be research focus and research locus. It was chosen because there are many problem reasons, namely: the high number of poor household; disruption of food security system; land dispute; limited employment opportunities; and the high number of uneducated people.

Due to this program is one of community empowerment program, so the main challenge in order to achieve food security at the poor household level is building human capacity of poor household through empowering community. Empowerment is "the expansion of assets and capabilities of poor people to participate in, negotiate with, influence, control, and hold accountable institutions that affect their lives (World Bank, 2002, p.11). Put the poor household as a subject to run this program is more important than just give fresh money or capital aid to each household because the concept of empowerment has focused on peoplecentered, participatory, empowering, and sustainable as explained by Chambers (1995). Besides that, Parpart, et al., (2002) explains that empowerment is a process of developing individual or group capacities through gaining education and skills in order to empower individual or groups to fight for a better quality of life. So, with empowering communities, they are expected to be able to recognize the potential and ability of their village, looking for alternative opportunities and solving problems, as well as being able to take the decision to use natural resources efficiently and sustainably to achieve independence. From this reality, then to achieve food security and alleviate poverty is needed process to empower rural community. It can be realized and developed starting from the poor household level through the concept of rural community's empowerment. If every rural household food security has been reached then automatically community food security, regional, and national levels will be achieved and also can alleviate poverty.

Based on the background, so the research questions in this study are how food security condition is in Ringinkembar Village Malang Regency before implementing Food Independent Village Program and how is rural community empowerment process through Food 
Independent Village Program in Ringinkembar Village, Sumbermanjing Wetan Sub-district to achieve food security and poverty alleviation in Malang Regency?

\section{RESEARCH METHOD}

In analyzing this case, this research uses qualitative approach with descriptive method. The data was collected from primary data such as: in-depth interview and observation, as well as from secondary data such as: related archives and documents. Furthermore, to analyze data was using interactive data analysis model by Miles and Huberman.

\section{DISCUSSION}

Food Independent Village Program is one of empowerment program that has aim to improve the ability of rural communities in developing the productive activities based on local resources, increased food security system (food availability, distribution, and consumption), increase purchasing power and household food access, so as to meet the nutritional adequacy of households, which ultimately impact on the decline in food insecurity and poor nutrition in rural areas, it is also line with the first goal of Millennium Development Goals (MDGs), which is to reduce poverty and hunger in the world by half by 2015 . In the process to empower community is done by four stages, namely: preparation, growth, development, and self-reliance. The purpose of these activities is to empower poor communities in order to realize and achieve food security system and alleviate poverty. The target of this program is poor household in food insecurity village. This program put poor people as the first priority.

\section{Condition before Implementing Food Independent Village Program}

Before implementing Food Independent Village Program, the food security condition in Ringinkembar Village is very alarming. Since 2005-2009, this village was hit by transitory food insecurity. Many villagers had difficulty to provide and fulfill food for their basic food standards. It is caused by various factors, as follows: First, poverty. Determination of the food insecurity status is based on 14 variables in the poverty indicators. There are $69 \%$ of total household population is living below the poverty line. Furthermore, as additional data obtained by researcher, the majority of household livelihoods are work as: farm worker, laborer, porters market, and cycle rickshaw. For a month, their average wage is approximately 600,000-700,000 IDR (60-70\$). While, based on official document from Sumbermanjingwetan Sub-district Administration mentioned that the Regional Minimum Wage is 1 million IDR (100 \$) per month per person. So, their wage is still below from the wage standard.

Second, disruption of rural food security system. According to the Food Security Council of Indonesia, the pillars of food security system consist of three food subsystem, namely: availability, distribution, and consumption. If one of 
these subsystems is hampered, so the other subsystem will also be affected and may be able to lead to food insecurity. Here are the problems that arise from each subsystem, as follows: (a) the failure of food availability subsystem is caused by various problems, such as: lack of capital access in the agricultural input (such as: seed, fertilizer, and pesticides), land degradation, limited agricultural land for planting rice, limited water resources, the use of traditional irrigation systems, and pest attacks; (b) the weak of food distribution subsystems also be one factor supporting food insecurity in this village. It is caused by the limited facilities and infrastructure such as: road, electricity, and telecommunication; and (c) limited access to food consumption subsystem are caused from the low income received by poor household.

Third, land dispute. Since a few years ago, this village had a problem about the land dispute owned by the villagers with Brawijaya Military Command Army $\mathrm{V}$. This problem has been going on for years and no resolution. Due to the land is still being disputed, the villagers are forbidden to grow crops in these areas. Forth, limited employment opportunities. Lack of employment opportunities can lead to the difficulty in obtaining a decent income. There is no factory established in this village. So, the majority of villagers work as farm workers, laborers, porter market, and cycle rickshaw. In addition, the unemployment rate is also high, which is about $38 \%$. The high levels of unemployment also give impact in food insecurity conditions because generally unemployment does not have money and weak in purchasing power.

Fifth, low quality of human resources (uneducated people). The quality of human resources can be measured from the level of education. Based on data from Ringinkembar Village Administration 2009 , community are able to complete the 9-year compulsory education (primary and secondary) is only $71 \%$. The low quality of human resources will affect to the level of ability in determining patterns of food production, distribution, and consumption. In addition, because their knowledge is also limited, they also cannot explore the potential of other resources that can be utilized for alternative staple food.

From various problems that happen in this village, if it analyzed with USDA (2012), these problems can classified as food insecurity, because it has three or more conditions that indicate food insecurity. Thus, in 2009, Malang Regency Government set Ringinkembar Village status as rural food insecurity. Provision of this status is reinforced by the enactment of the Decree of Malang Regent No.180/372/KEP/421.013/2009. With this enactment indicates that food security conditions in Ringinkembar Village are very low, need a good treatment, and serious attention to avoid occurrence of chronic food insecurity.

\section{Rural Community Empowerment through Food Independent Village}

The implementation of Food Independent Village Program held for four years, from 2009 until 2013. The process in empowering community is implemented 
through four stages, namely start from: preparation, growth, development, and end on self-reliance stage: First, preparation stage. Preparation stage is the initial stage to implement Food Independent Village Program. This stage began in 2009 until 2010. The activity of preparation stage is performed starting from: (a) Screening target location. The process of target site selection is carried out by the Central Government through Ministry of Agriculture. Site selection is done in each level area which is starting from: Malang Regency, Sumbermanjing Wetan Subdistrict, and Ringinkembar Village. (b) Assigning the assistant of Food Independent Village Program. After screening target location is selected, the next step is assigning the assistant of Food Independent Village Program. The assistant program is not Ringinkembar villager. This assistant was appointed by the Food Security and Implementing Counseling Agency to accompany the villager in implementing these programs with the contract system until self-reliance stage implemented. This assistant has purpose to: provide socialization for all the villagers, survey the number of poor household based on basic household data, and survey for determine local potentials that can be developed within the group. (c) Assigning a Food Village Team. This team has duty to: alleviate poverty, realize food security at the household level, and give advocate to the head of Ringinkembar Village. This team is prepared to replace the role of assistant of Food Independent Village Program after the self-reliance stage was implemented or the program ends. So, this team has self-skill and be independence in empowering community and developing food security in a sustainable manner. (d) Establishing of Rural Financial Institution. This institution has responsible to manage finances as productive capital of affinity groups becomes productive community service agencies. (e) Assigning affinity groups. An affinity group is a member of the group that was tied with a sense of unity and togetherness by friendship and family networks to carry out economic activities of business together. Member of affinity groups is come from poorer household which collected from survey of Basic Household Data. The formation of affinity group was done by Food Village Team which formed are four groups, as follows: Etawa Mapan I, II, III, and IV. The formation of affinity groups with the name of goat is based on the results of household survey which potential for the right business to be developed by poor are raising goat. It was established by Degree of Malang Regent No.180/372/KEP/421.013/2009 on November 18, 2009. (f) Socializing the activities of Food Independent Village Program. This socialization is not only mean how these programs can be understood by the community both substance and procedure, but it can be a part of the socialization process of community empowerment, which is expected can develop a critical awareness, change behavior, and attitude. Participants' socialization program was attended by the entire villagers. The goal is to provide an overall picture associated with these program and related aspects in it. (f) Channeling social fund for 
productive business. After the villagers understand the goal of these programs, then the final of preparation stage is channeling social fund for productive business to each affinity group's members. There are 100 Etawa goats which distributed to four groups that have been formed, namely: Etawa Mapan I, II, III, and IV. Each group consisted of 25 people. Etawa goat is selected to develop productive business because the availability of vast grasslands and the skill of community in raising goat. With the distribution of Etawa goats to each affinity groups member, then the first final stage of Food Independent Village Program have been completed and it will proceed with the second stage, namely: the growth stage.

Second, growth stage. Growth stage was implemented from 2010 to 2011. At this stage, actually agricultural sector is the main sector for securing people's right to food and alleviating poverty. Unfortunately, it is not all rural areas have the same condition. Normally, agricultural sector is the basis of the staple food source and has flagship product like rice. But it is look different with this village, because the availability of rice is limited to produce. It is also line with the statement of Maxwell and Slater (2003); Webb, et al., (2006) which stated that: "over time the emerging consensus was that sufficient agricultural output did not automatically result in reduced food insecurity, either transitory food shortages or chronic hunger." Seeing these conditions, so the activities carried out focused on how to foster community empowerment by utilizing the availability of local potential which is owned by local community besides increasing rice production. The process of community empowerment in growing food security system is starting from: (a) Empowering communities in food availability subsystem is done through several activities, namely: first, foster the spirit of learning for farmers to improve rice production with agricultural intensification concept. According to Gill (2002) stated that: to achieve long-term food security, it can be improved by encouraging farmers to pursue sustainable intensification of production through the use of improved input. Therefore, every farmer is invited to be motivated and willing to learn about: how to choose the quality of seeds that should be used, how to cultivate agricultural land, how to manage irrigation system, how to provide proper fertilizer, and how to eradicate pests. By applying the fifth way of agricultural intensification, it will expect can increase the rice production. So, it can fulfill the rice consumption for all villagers. Second, foster the spirit of farmers to continue and optimize the potential of plantation crops that they have. Third, foster the entrepreneurial spirit in raising goats. It has purpose to increase additional income and reduce unemployment. (b) Empowering communities in food distribution subsystem. In this stage, empowering community in food distribution subsystem is done with fostering a sense of mutual cooperation and community participation in building rural roads. To facilitate the flow of the economic transportation and distribution of food within or between villages, the assistant of Food Independent Village 
Program, Food Village Team, village administrators, and the community have self-motivation to build rural road with mutual cooperation, while waiting for help in repairing the road from the government. Self-motivation was an essential part of empowerment (Lord \& Hutchison, 1993, p. 12). With self-motivation, so communities are willing to participate and empowered in repairing damaged roads. (c) Empowering communities in food consumption subsystem. In most households, the majority of food consumed by household members is purchased either from markets or grocery stores to be eaten at home or outside the home. The amount of money that a household spends on food, it provides insight into how adequately it is meeting its food needs (Nord, et al., 2007, p.21). Due to the most household has limited money, so the process of empowering community in food consumption subsystem performed by growing knowledge and skills in creating creative community to take advantage of the home garden in an effort to create household food security. Community can utilize their home garden to plant a variety of staple food such as: peppers, tomatoes, cabbage, cucumbers, string beans, cabbage, eggplant, taro leaves, cassava, sweet potato, ginger, turmeric, lemongrass, and etc.; keeping livestock such as: chicken, goat, and cow; and maintaining fish, such as: tilapia, carp, and catfish. The purposes of the utilization of home gardens are: to help ease the burden of household food expenditure, to provide food needs, to develop a sense of pride to the villagers if it is able to harvest and consume plant produced from their plant, and to get side income if the result is excess, they can sell to the market. If intensively manage, every household can realize food availability and sufficient for food consumption.

Third, development stage. The next stage of Food Independent Village Program is development stage. This stage was carried out in 2011 to 2012 within a period of one year and begins in the third year. At this stage, poor people begin to feel the changes in their household food security conditions. Furthermore, for the process of community empowerment still remains focused on the development of food security system which is a continuation of the growth stage. The process of community empowerment is done through increasing several activities, as follows: (a) Empowering community in developing food availability subsystem is done through several activities, namely: first, building the capacity of farmers to increase rice production by agricultural intensification. Farmer began to implement agricultural intensification ways to increase their rice production. Despite the limited land to growth paddy, but with the development of raising goat as their productive business, the farmer are able to buy and use good quality of seed, fertilizer, pesticide, etc. to increase their output production. Second, developing and managing potential plantation, such as: sengon wood, teak wood, and patchouli leaves. Sengon and teak wood is processed into various households furniture's such as: table, chair, window, cabinet, bookcases, and so forth, while patchouli leaves is processed into patchouli oil that can be used as raw materials of cosmetic, 
perfumes, and medicines. This activity can increase their innovation, skill, and ability. Moreover, it can used to increase their additional income. Third, developing several byproduct of raising goats. The Village Food Team, the assistant program, staff of Department of Agriculture, and staff of Food Security and Implementing Counseling Agency provide training and mentoring to the affinity groups member about how to develop a byproduct of raising goat. Communities trained and assisted in developing and utilizing the results other than just raising goat because goat is one of animal that very useful and economically valuable if they know how to develop it. So, there are several byproduct of raising goat that can process by the groups member, such as: (a) Etawa goat milk, (b) compost fertilizer from goat's urine and feces, and (c) leather handbags, belts, wallet from goatskin. Hence, overall the byproduct of raising goat aims to add their income. Besides that, these activities is done in empowering because the groups member is not only raising and breeding goats but they can develop and empower themselves to process the byproduct. (b) Empowering community in developing food distribution subsystem. In the developmental stage, food distribution in this village become smoothly, because the road conditions had improved. The villager can repair the damaged road with other villager if had road problem. So far in third year, the road condition still good. It has positive impact to the villagers because it can facilitate the flow of food distribution within and outside of this village. Besides that, when the harvest season and they want to sell their crops to the other village become easier. (c) Empowering community in developing food consumption subsystem. At this stage, the community still continues the activities from previous stage. Communities are empowered to continue in planting and cultivating variety of food crops in their home garden. Thus, their food consumption become diverse and can save money for food shopping in daily. The benefits derived from planting food crops in home garden, besides it can utilized by the community, the community is also empowered to have the ability to manage their alternative food consumption subsystems that can be consumed on a daily basis.

Last, self-reliance stage. It was implemented in 2012 to 2013. This program has entered the stage of selfreliance. This stage is the final stage of Food Independent Village Program. In this stage, the poor household already has the capital and the ability to continue and optimize their potential. Through the training, skill enhancement, poor people who previously did not have the skills at all, at this stage the poor have already had skills and ability to develop independently. Community self-reliance in food availability subsystem. It can be seen from: first, farmers become more independent in managing their limited farm land and the results can be maximized with the agricultural intensification. A rice production in the fourth year is also increased. It is important to improve household food security. Although not significant, it is not problem because land use is also limited, it 
still fixed with the total paddy farm land of 1.5 ha.

\section{Figure 1. Rice Harvest in Ringinkembar Village 2009-2012}

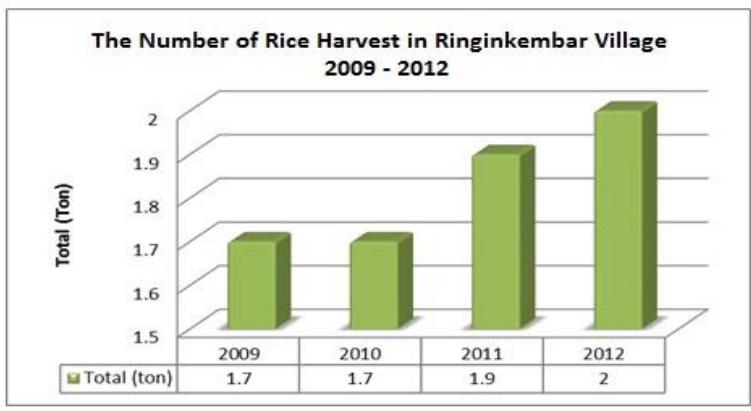

Source: Food Security and Implementing Counseling Agency of Malang Regency, 2013.

Based on figure 1, it shows that by using the agricultural intensification on a limited land, it can also increase the rice harvest. So, the agricultural intensification efforts are suitable to be applied in a limited paddy farm land owned by the villagers. Second, community self-reliance in managing and selling the plantation product. Community can sell the various type of furniture and patchouli oil to other villagers in need. So, the extra income is perceived by the community.

Third, community self-reliance in raising, breeding, and selling the byproduct from Etawa goat. The members of affinity group have the independence to sell the byproduct that has been made, so they can get additional income. The additional income generated can be used as additional funds in buying food or other needs. Moreover, besides these activities, the following is an increasing number of Etawa goat which developed by affinity groups in raising goat process.

Table 1. The increasing of Etawa Goat belong Affinity Groups 2010-2012

\begin{tabular}{clcccc}
\hline \multirow{2}{*}{ No. } & \multirow{2}{*}{ Name of Group } & $\begin{array}{c}\text { Number of } \\
\text { members (people) }\end{array}$ & $\begin{array}{c}\text { Initial capital } \\
\text { of goat 2010 }\end{array}$ & \multicolumn{2}{c}{ Number of goats } \\
\cline { 5 - 6 } & & 25 & 25 & 55 & $\mathbf{2 0 1 1}$ \\
\hline 1. & Etawa Mapan I & 25 & 25 & 51 & 52 \\
2. & Etawa Mapan II & 25 & 25 & 52 & 57 \\
3. & Etawa Mapan III & 25 & 25 & 54 & 60 \\
4. & Etawa Mapan IV & $\mathbf{1 0 0}$ & $\mathbf{1 0 0}$ & $\mathbf{2 1 2}$ & $\mathbf{2 3 5}$ \\
\hline
\end{tabular}

Source: Food Security and Implementing Counseling Agency of Malang Regency, 2013.

Based on table 1, it shows that the number of goat increase from year to year by previous group (Etawa Mapan I, II, III, and IV). In 2010, the initial capital of goat channeled to affinity groups members as much as 100 goats. In 2011, the number of goats was successfully bred were 112 goats, so the total number of goat was 212 goats. On average each member has two (2) goats. But unfortunately, in 2012, the number of goat is only 235 goats. An increasing number of goats were 
developed only 23 goats. The number of goats did not increase significantly in 2012 because some goats sold as business capital in self-reliance stage and partly of goat die because of disease attack. So, the number of goats owned by majority members as much as two (2) goats only. Only minority members have three (3) goats. This will greatly affect to the rolling time in distributing goat to other members. But this condition is not become a significant problem in delivering goat assistance. Seeing these results, in 2013, the Food Security and Implementing Counseling Agency, the head of Ringinkembar Village and the affinity group agreed to add one more group to receive assistance revolving goat. The new group was named Etawa Mapan V that consists of 25 people. Formation of this group is based on the needs of poor household who have not received assistance. So, the process of community empowerment to raising goat can be continued by the other poor household.

Besides that, year by year, the number of poor household is reduced. Based on data from Ringinkembar Village Administration, in 2009, the number of poor household is 1,047 household and after implementing these programs, in 2013, the number of poor household is 935 households: Community self-reliance in food distribution subsystem. The flow of food distribution is able to smooth. Level of food distribution was achieved by the proper functioning of rural infrastructure and facilities that built by the community in a participatory manner and have impact on people's welfare and the surrounding villages because they can access these roads as well; Community self-reliance in food consumption subsystem. It was reflected on the change in food consumption patterns are varied, nutritionally, balanced, and secure. The poor people are no longer being dependent in the availability of rice because the poor can take advantage from other types of food to meet the daily from their home gardens and can minimize the household food expenditure.

After all stages of Food Independent Village Program were already done to implement, in 2013, Ringinkembar Village become more self-reliance. Selfreliance who received by community is resulting from the process of learning. Community who follow the process of good learning will gradually gain power, strength, and abilities that are useful in the decision-making process on their own. The independence of food security has been formed and embedded in the soul of poor rural communities. So, the implementation of Food Independent Village Program is the best way in empowering community with several activities in every stage to achieve food security and poverty alleviation. Despite the self-reliance stage is the final stage but this program will continue and sustainable. In reducing poverty, it is still an enormous challenge because in an effort to reduce poverty, it is not just the process how to make the number of poverty was reduced, but is more focused on how to make the poor become not poor again. This is the real challenge in alleviating poverty.

Besides that, the donor support to empowerment processes is most effective around issues that are seen as pressing 
challenges for the poor people with natural resources based livelihoods, as expressed by Prato and Longo, 2012). Through this program, the poor are directed to develop the other potential resources. The villagers can see that the other potential can be raised to be used as the main base of economic and empowerment activity. Increasing rural economic development based on local potential aims to increase purchasing power, fulfill people needs, and raise community awareness in order to develop the available potential as their capital that they have.

Based on the implementation of these programs, moreover, if analyze with categorized by Pranaka and Prijono (1996), the process of empowering community through these programs are included in the category of transition phase, namely: from initiation phase to the participatory phase. It is said to be in the initiation phase because all processes of community empowerment comes from the government and community just doing what is planned by the government. It shows with the bureaucratic involvement in the community empowerment process. It begins in the first stage of these programs, namely: at the preparation stage. The involvement of bureaucracy apparatus in various levels can provide positive and negative impact for the overall process of community empowerment. The positive impact is the bureaucratic apparatus can monitor the activities ranging from making proposal until evaluating the implementation of these programs, developing a good relationship among related bureaucracy, as well as growing the village institution. While, the negative impacts is that it can inhibit the process of community development, weakening the community spirit and innovation in developing their capabilities. Due to at the transition stage, the process of community empowerment also cannot be said reached perfectly in the participatory phase. As we know that at the participatory phase, the community has been actively involved in development activities towards independence. Actively involved here refers to the overall role of the community who are involved in every stage activities, among in the preparation of proposals, implementation, and evaluation. But, the role of community has been involved since the preparation stage until self-reliance stage. Nevertheless, the villagers were able to achieve food self-reliance. This is because in an effort to empower community held for four (4) years in a row.

Thus, after implementing Food Independent Village Program, the food security conditions are also gradually improved in every food security system. Various problems that plagued this village can also be completed in stages, starting from: the reduced number of poor households, improving household food security system of the poor, and increasing the skill of the villagers. While, the problem is still not resolved until the end of self-reliance stage is a matter of land dispute. Through the implementation of Food Independent Village Program, nowadays, poor household have ability to achieve food security and nutrition so they can lead healthy and productive lives from day to day in a sustainable manner. 


\section{CONCLUSION}

The process to empower rural community through Food Independent Village Program in Ringinkembar Village was successful implemented. This successfulness can be seen from the selfreliance of household food security condition and the number of poor was reduced in a sustainable manner after implementing this program. Building on inherent strengths and capabilities of community became part of the impetus for their involvement in an empowerment process. The poor household also has skill to develop their productive business, can utilize their local potential, can add their household income, and can increase their purchasing power. Besides that, it can grow the village institution become well than before. Moreover, the result of this implementation also gives benefit to other village in order to achieve food security and alleviate poverty. This village used as an example to establish three (3) food insecurity village are not finished in implementing these programs also, namely: Gunungsari Village in Tajinan Sub-district, Ngadireso Village in Poncokusumo Sub-district, and Pait Village in Kasembon Sub-district where located in surrounding Malang Regency area.

\section{REFERENCES}

Chambers, R. (1995). Poverty and Livelihoods: Whose Reality Counts?. Environment and Urbanization. 7:173-204.
Food Security Council of Indonesia. (2009). Draft 1: Indonesia Tahan Pangan dan Gizi 2015. Retrieved from:

http://bkp.bangka.go.id/donlot/tahanpangan-dan-gizi-2015_datastudi.pdf

Food Security Council of Indonesia, Ministry of Agriculture, and WFP. (2009). A Food Security and Vulnerability Atlas of Indonesia 2009. Jakarta: PT. Enka Deli.

Food Security and Implementing Counseling Agency of Malang Regency. (2013). Food Independent Village Program Report 2012. Kepanjen: Food Security and Implementing Counseling Agency of Malang Regency.

Gill, G. (2002). Applications of Appropriate Agricultural Technology and Practices and Their Impact on Food Security and the Eradication of Poverty: Lessons Learned from selected Community Based Experiences. London: Overseas Development Institute.

Life Sciences Research Office. (1990). Core Indicators of Nutritional State for Difficult to Sample Populations. The Journal of Nutrition, 120: 1557-1600.

Lord, J., \& Hutchison, P. (1993). The Process of Empowerment: Implication for Theory and Practice. Canadian Journal of Community Mental Health, 12:5-22.

Maxwell, S., \& Slater, R. (2003). Food Policy Old and New. Development Policy Review, 21(5-6):531-553.

Parpart, J., Rai, S., \& Staudt, K. (2002). Rethinking Em(power)ment, Gender 
and Development: An Introduction. Rethinking Empowerment. London: Routledge.

Nord, M., Andrews, M., \& Carlson, S. (2007). Household Food Security in the United States, 2006. EER-49, U.S. Dept. of Agriculture, Econ. Res. Serv. November 2007.

Pranaka, A.M.W., \& Prijono, O. S. (1996). Pemberdayaan: Konsep, Kebijakan dan Implementasi. Jakarta: CSIS.

Prato, B., \& Longo, R. (2012). Empowerment of Poor Rural People through Initiatives in Agriculture and Natural Resources Management. Rome: IFAD (International Fund for Agricultural Development).

Ringinkembar Village Administration. (2009). Official Document of Ringinkembar Village 2009. Retrived from collecting data in the field during study.

Central Board of Malang Regency Statistics. (2010). Malang Regency in Figures 2009. Malang: Planning Board of Malang Regency.

Tadjbakhsh, S. (2008). Human Security: Looking Back before Looking Forward. In A Paper for ICHSWA Conference. Retrieved from http://www.birjand.ac.ir/ichswa/dow nloads/Dr\%20Tajbakhsh's\%20Paper \%20in\%20ICHSWA.pdf

UNDP. (1995). Human Development Report 1995. New York: Oxford University Press.

USDA. (2012). Food Security in the U.S. Retrieved from http://www.ers.US\$ a.gov/topics/food-nutritionassistance/food-security-in-the-
us/measurement.aspx\#.UbqhkOfOHZ I

Webb, P., Coates, J., Frongillo, E.A., Rogers, B., Swindale, A., \& Bilinsky, P. (2006). Measuring Household Food Insecurity: Why It's so Important and yet so Difficult to do. The Journal of Nutrition, 136(5):1404S-1408S.

World Bank. (2002). Empowerment and Poverty Reduction: A Sourcebook. Washington, D.C.: World Bank. 